\title{
THE LEGAL STATUS OF SUSTAINABLE DEVELOPMENT IN THE NIGERIAN ENVIRONMENTAL LAW
}

\author{
Emmanuel E. Okon*
}

\begin{abstract}
Sustainable development underpins environmental governance in all jurisdictions, but its legal status is still controversial. The major problem which Nigerian courts and policy-makers will continue to face when implementing and enforcing sustainable development in environmental governance is whether it is a moral or legal concept and, if it is the latter, whether it has metamorphosed into a legal principle or the rule of law having a normative value. This article argues that the legal status of sustainable development in Nigeria depends on which legal instrument it is incorporated and whether it is expressed in a general or specific mandatory language. Also, its legal status depends on the pronouncements of Nigerian courts on it. Methodologically, the qualitative content analysis is used to ascertain the legal status of sustainable development in the statutes and case law examined. In order to enhance the implementation and enforcement of sustainable development in the Nigerian environmental law, the conclusion of this article adopted as recommendations the latter part of its argument that sustainable development should be made an essential part of the right to life, the relevant constitutional provisions on the environmental should be amended to reflect it and, in addition, section 20 of the Constitution of the Federal Republic of Nigeria 1999 should be transferred to Chapter IV of the Constitution, which deals with fundamental human rights.
\end{abstract}

Keywords: Sustainable development, legal status, implementation, enforcement and qualitative content analysis.

DOI: http://dx.doi.org/10.4314/jsdlp.v7i2.6

* LL.B (UniUyo); LL.M, MBA (Ife); MILR (Ibadan); PhD (Wales); BL; Senior Research Fellow and Head, International Law Department, Nigerian Institute of Advanced Legal Studies, University of Lagos Campus, Akoka, Yaba, Lagos, Nigeria. emmyokon@yahoo.com. 


\section{INTRODUCTION}

The major problem Nigerian courts and policy-makers face when enforcing, implementing or promoting sustainable development in environmental governance in Nigeria is whether it is a moral or legal concept. If it is the latter, has it metamorphosed into a legal principle or the rule of law having a normative value? Regrettably, most literature on sustainable development ignored the fact that enforcement, implementation or promotion of sustainable development, especially by the courts and policy makers, is a matter of legal reasoning. ${ }^{1}$ Theoretically, legal reasoning is a hierarchical form of reasoning which established relationships of inferiority and superiority between units and levels of legal discourses. ${ }^{2}$ The status of either a moral or a legal concept is a measure of its true salience within the legal debate and its power to affect legal decision-making. ${ }^{3}$ Therefore, the normative value of sustainable development bestows on it its legal weight, which in turn influences its application in environmental governance, legislative and academic discourses and by the courts in settlement of the environmental dispute. ${ }^{4}$

Determining the legal status of sustainable development requires identifying its position within the hierarchy of environmental law. Judge Trindade rightly pointed out that while a great part of contemporary

1 For example, Fagbohun rightly pointed out that environmental laws and policies in Nigeria are a reflection of the phases of the country's development style, the orientation that unfortunately has not augured well for sustainable development. Meanwhile, the legal status of sustainable development can radically influence the interface between law and development. See Lanre Fagbohun, Law and Policy in Nigeria: The Dilemma of the Concept of Sustainable Development (Lagos State University Centre for Environment and Science Education 1999) 1, 37-38.

2 Martti Koskenniemi, 'Hierarchy in International Law: A Sketch' (1997) 8(4) European Journal of International Law 566.

3 John M Gillroy, 'Adjudication Norms, Dispute Settlement Regime and International Tribunals: the Status of Environmental Sustainability in International Jurisprudence' (2006)42 (1)Stanford Journal of International Law 1, 2.

4 Koskenniemi, M. (n 2) 568; According to Gillroy, normative standard is the 'value' that defines the logical parameters of a positive law....' Gillroy, J. M. (n 3) 5. This is contrary to Marong's opinion that the usefulness of sustainable development does not depend upon its status as a customary international law. Marong, B. M., 'From Rio to Johannesburg: Reflections on the Role of International Legal Norms in Sustainable Development' (2003) vol 16 Issue 1 Georgetown International Environmental Law Review 21, 56 and 60-61. 
expert writing continues, somewhat hesitantly, to refer to sustainable development as a 'concept', there are also those who seem today to display their preparedness and open-mindedness to admit that it has turned out to be a general principle of international law. ${ }^{5}$ Olawuyi argues that sustainable development has become one of the recognized general principles of international environmental law, and there is evidence to suggest that it is maturing into a custom of international law. ${ }^{6}$ Interestingly, few commentators support the idea that sustainable development has attained the status of international custom. ${ }^{7}$ On the contrary, Lowe contends that sustainable development lacks a fundamental norm-creating character to constrain actions; hence it cannot become a primary rule of law. ${ }^{8}$ Similarly, lack of a precise definition of sustainable development led Bratspies to note that the 'widespread agreement on a principle does not translate into an agreement on the principle's normative content'. ${ }^{9}$ From the perspective of Birnie and others, notwithstanding the breadth of international endorsement of the concept of sustainable development, conflicting claims about the concept's specific normative implications abound and

5 See Judge CanÇado Trindade's Separate Opinion in Pulp Mills on the River Uruguay (Argentina v. Uruguay) Judgment, [2010] I.C.J. Reports 125 particularly [138] 177.

6 Damilola S. Olawuyi, The Principles of Nigerian Environmental Law (Afe Babalola University Press 2015) 75. Olawuyi's assertion is based on the fact that 'sustainable development has been vastly recognized as the yardstick for measuring development in many countries and internationally... Currently, there are over 300 international legal instruments in addition to other soft law declarations, guidelines and General Assembly Resolutions that have identified and recognized the principle of sustainable development. ibid.

7 David Luff, 'An Overview of International Law of Sustainable Development and a Confrontation between WTO Rules and Sustainable Development' (1996) 29 Belgian Review of International Law 90, 94-97. As far as Gillroy is concerned, sustainable development has become an established legal principle of international law and may be gaining momentum toward general acceptance as a norm of customary international law. See Gillroy, JM (n 3) 51.

8 Vaughan Lowe, 'Sustainable Development and Unsustainable Argument' in Boyle, A and Freestone, D (eds), International Law and Sustainable Development: Past Achievements and Future Challenges (Oxford University Press 2001) 19, 31 and 34.

9 In Bratspies' opinion, the problem with sustainable development is that the same term means very different things to different thinkers acting in a variety of contexts. Rebecca M. Bratspies, 'Rethinking Decisionmaking in International Environmental Law: A Process-Oriented Inquiry into Sustainable Development' (2007) 32 (2) Yale Journal of International Law 363, 364. 
dispute over its application is exceedingly difficult to resolve due to a lack of comparative consensus on its meaning, normative uncertainty and how to give it concrete effect in individual cases, and the absence of justiciable standards for review. ${ }^{10}$ Stone asserts that sustainable development is artfully vague. ${ }^{11}$

Indeed, a few authors have displayed self-contradictory positions on the legal status of sustainable development. ${ }^{12}$ For instance, Sands, in the second edition of his Principles of International Environmental Law, refers to sustainable development as a general principle of international environmental law. In the third edition of this book published nine years after, Sands and his co-authors argue that in the absence of clear judicial authority, and in view of the conflicting interpretations under state practice, it is frequently difficult to establish the parameters or the precise international legal status of each general principle or rule [sustainable development is listed by the authors as No. 4 of such general principles or rules]'. In the introduction of their discourse on sustainable development, the authors said 'The general principle that States should ensure the development and use of their natural resources in a manner that is sustainable. ... Although the idea underlying the concept of sustainable development has a long history ... the general principle of sustainable development ... The term now appears with great regularity ...'13 The authors wrote in their conclusion 'International law recognizes a principle (or concept) of "sustainable

10 Patricia Birnie, Alan Boyle, and Catherine Redgwell, International Law and the Environment (3rd edn, Oxford University Press 2009), 125-126. In these circumstances, Birnie and others argue further that unless specific international action has been agreed, states retain substantial discretion in interpreting or deciding on what constitutes sustainability as well as giving effect to it. Probably, not really the intention of the authors, they further expressed their doubt concerning the legal status of sustainable development when in their discourse on 'The Legal Status of Sustainable Development' they refer to it twice as a 'concept' on page 125, then later referred to it once as an'alleged principle' on page 126 and finally referred to it twice as a 'concept' on page 127.

11 Christopher D. Stone, 'Ethics and International Environmental Law' in Daniel Bodansky and others (eds), The Oxford Handbook of International Environmental Law (Oxford University Press 2007) 291, 308.

12 Philippe Sands, Principles of International Environmental Law (2nd edn, Cambridge University Press 2003) 163; Philippe Sands and others, Principles of International Environmental Law (3rd edn, Cambridge University Press 2012) 206-217.

13 Philippe Sands and others (n 12) 207. 
development". The term needs to be taken ...' ${ }^{14}$ By referring to sustainable development as a general principle, concept and term, Sands and his co-authors indirectly confirm their position in the introduction of Chapter 3 of their book that 'it is frequently difficult to establish the parameters or the precise international legal status of each general principles'. ${ }^{15}$

In the same vein, Olawuyi ${ }^{16}$ started his discourse on 'sustainable development as a key principle of international environmental law' by referring to it as a principle, which is at the very root of international environmental law. ${ }^{17}$ In the fourth and fifth paragraphs of his discourse, he referred to sustainable development as a concept. ${ }^{18}$ More interestingly, after he quoted the decision of the Permanent Court of Arbitration (PCA) in the Arbitration Regarding The Iron Rhine ('Ijzeren Rijn') Railway (Belgium $v$ Netherlands) ${ }^{19}$ that 'the requirement where development may cause significant harm to the environment, there is a duty to prevent, or at least mitigate such harm has now become a principle of general international law', he then concluded that the rapid ascendancy of the concept of sustainable development in national laws, international treaties, and case law all provide evidence that it has gained recognition as a principle relevant to an international law on the environment and natural resources. ${ }^{20}$ Respectfully, Olawuyi's perspective ignores the fact that sustainable development can be expressed in international and national laws, including the constitutions, in a variety of ways that reduces or enhances its legal status other than as a principle.

What is more, Olawuyi did not inform his readers that the decision of the PCA's Award he quoted was in the context of the precautionary principle. In Iron Rhine (Belgium $v$ Netherlands) Award, ${ }^{21}$ the Arbitral Tribunal while recalling the observation of the International Court of

14 ibid 217.

15 ibid 187.

16 Damilola S Olawuyi (n 6).

17 ibid 74.

18 ibid 75 and 76.

19 Iron Rhine ('ljzeren Rijn') Railway (Belgium v Netherlands) [2005] Perm. Ct. Arb. 1, 28-29 and 49. Hereinafter referred to as Iron Rhine (Belgium $v$ Netherlands) Award.

20 Damilola S Olawuyi, (n 6) 77.

21 See Iron Rhine ('ljzeren Rijn') Railway Case (Belg. v. Neth.) [2005] Perm. Ct. Arb. $1,28-29,49$. 
Justice (ICJ) in the Gabèíkovo-Nagymaros Projects (Hungary/Slovakia), Judgment ${ }^{22}$ decided that sustainable development was one of the emerging norms of environmental law, whose current status was uncertain. Unlike the ICJ, which initially regarded sustainable development as an emerging norm of international law but ended up referring to it as a concept, the Arbitral Tribunal started by considering sustainable development to be a concept and ended by cautiously noting that

[t]his need to reconcile economic development with protection of the environment is aptly expressed in the concept of sustainable development' (Gabèíkovo-Nagymaros (Hungary/Slovakia), Judgment, I.C.J. Reports 1997, p. 7 at p. 78, para. 140). And in that context the Court further clarified that 'new norms have to be taken into consideration, and ... new standards given proper weight, not only when States contemplate new activities but also when continuing with activities begun in the past' (ibid.). In the view of the Tribunal this dictum applies equally to the Iron Rhine railway. ${ }^{23}$

Indeed, one would have expected the Arbitral Tribunal to be very specific in ascertaining the legal status of sustainable development after it had recognized that there is considerable debate as to what, within the field of environmental law, constitutes rules or principles; what is soft law; and which environmental treaty law or principles have contributed to the development of customary international law. ${ }^{24}$ Notwithstanding the Arbitral Tribunal's earlier position not to enter into those controversies, ${ }^{25}$ it went ahead to state with certainty that

22 [1997] I.C.J. Reports 7. This case concerned the use of the Danube River by Hungary and Slovakia for a significant hydroelectric dam project involving two facilities (one up-river and the other down) and the opportunity for the upriver dam to hold the water so that the backup could be used for 'peak-power' production by the down-river facility. The project was established in 1977 through a bilateral treaty. In 1989, Hungary suspended the project. In 1992, Hungary tried to pull out of the treaty because Slovakia had decided to proceed with a unilateral 'Variant C' of the project, which would produce power by diverting eighty percent of the flow of the Danube away from Hungary. Hungary pleaded that Variant $\mathrm{C}$ was a breach of the treaty.

23 ibid [59] 66.

24 ibid [58] 66.

25 ibid. 
the principles of state responsibility for extra-territorial environmental harm and precaution have now become principles of general international law. ${ }^{26}$ With regard to the former principle, the Arbitral Tribunal authoritatively referred to the Advisory Opinion of the ICJ in Legality of the Threat or Use of Nuclear Weapons, Advisory Opinion ${ }^{27}$ where the court expressed the view that:

[t]he existence of the general obligation of States to ensure that activities within their jurisdiction and control respect the environment of other States or of areas beyond national control is now part of the corpus of international law relating to the environment. ${ }^{28}$

Concerning the precautionary principle, the Arbitral Tribunal did not just stop at deciding that is has become a general principle of international law, but went further to state thus: 'Environmental law and the law on development stand not as alternatives but as mutually reinforcing, integral concepts, which require that where development may cause significant harm to the environment there is a duty to prevent, or at least mitigate, such harm'. ${ }^{29}$ Interestingly, the integration of environmental protection into developmental project places an obligation on the parties concerned to, as far as possible, reconcile the conflicting interests between the two issue areas. It is not incontrovertible that reconciliation of development and environment interests is the sub-stratum of sustainable development. Regrettably, even though this is inherent in the Arbitral Tribunal's later decision in paragraph $223^{30}$ of its award, it did so only within the context of the precautionary principle.

26 ibid [59] 66.

27 I.C.J. Reports [1996] (I) 22.

28 ibid [29] 241-242.

29 ibid [59] 66.

30 Applying the principles of international environmental law, the Tribunal observes that it is faced, in the instant case ... with the effect of the exercise of a treaty guaranteed right of one state in the territory of another state and a possible impact of such exercise on the territory of the latter state. The Tribunal is of the view that, by analogy, where a state exercises a right under international law within the territory of another state, considerations of environmental protection also apply. The exercise of Belgium's right of transit, as it has formulated its request, thus may well necessitate measures by the Netherlands to protect the environment to which Belgium will have to contribute as an integral element of its request. The reactivation of the Iron Rhine railway cannot be viewed in isolation from the environmental protection measures necessitated by the intended use of the railway line. These measures are to be fully integrated into the project and its costs. ibid 116. 
From the foregoing, it is certain that the legal status of sustainable development in environmental law is still controversial. No doubt, Nigeria is one of the countries that has integrated sustainable development into its environmental law and practice, ${ }^{31}$ albeit not specifically. The primary objective of this article is to ascertain the legal status of sustainable development and how its implementation and enforcement can be enhanced within the context of the Nigerian environmental law. This article argues that the legal status of sustainable development in the Nigerian environmental law depends on the pronouncements of Nigerian courts on it. Where the courts have not made such pronouncements, then ascertaining its legal status depends on whether or not it is incorporated into a soft law or an enforceable municipal law on the environment. Indeed, within the context of such legislation, the legal status of sustainable development will further depend on whether or not it is placed in the preamble, recitals or the operative part and, if in the latter part, whether it is expressed in a general or specific mandatory language. ${ }^{32}$

Furthermore, the effective implementation and enforcement of sustainable development in the Nigerian environmental law requires integrating it expressly and directly into the Constitution of the Federal Republic of Nigeria 1999 as altered ${ }^{33}$ as an essential element of the right to life and the relevant constitutional environmental provisions, as well as transferring section 20 , which is the core constitutional environmental provisions, to the fundamental human rights chapter of the Constitution.

31 For instance, in France, Article 2.6 of the 2005 French Constitutional Amendment incorporates the French Chartedel'environnement, Charter for the Environment of 2004, into the Preamble of the France Constitution. Para 7 of the Preamble and Article 6 of the Charter integrates sustainable development into France Constitutional law; For the United Kingdom see section 4(1) of the UK Environment Act 1995 and section 79 of the Government of Wales Act 2006; For South Africa see section 24 of the Constitution of South Africa and sections 1(1), 2(1) 4(a) and 26(2) (a) and (b) of the National Environmental Management Act 107 of 1998; for Uganda see article 245 of the Uganda Constitution 1995 and sections 2(2)(c) and (d) and 45(3) of the 1995 National Environmental Act of Uganda.

32 See generally BR Atre, Legislative Drafting, (4th edn, Universal Law Publishing Co 2014)42-49; Helen Xanthaki, Thornton's Legislative Drafting (5th edn, Tottel Publishing Ltd 2013) 235-239.

33 Hereinafter referred to as the 1999 Constitution. 
Suffice it to say from the outset that although contemporary Nigerian environmental law is rooted in treaties, customs, general principles of international law recognized by civilized nations, judgments of international court, United Nations General Assembly Resolutions, Declarations of Principles of United Nations or by ad hoc conferences and proposals of the International Law Commission, ${ }^{34}$ qualitative content analysis of the legal status of sustainable development is limited to only Nigerian policies, legislation and case law. ${ }^{35}$ The truth is that most environmental problems, like climate change and over exploitation of marine fisheries, have domestic roots even though their effects are transnational, thus requiring cohesive and concerted actions by states. Slaughter and Burke-White have carefully distinguished between the classical model of international law which was designed to address traditional international law problems such as state to state cooperation and the treatment of one state's nationals by another state on the one hand, and contemporary international law problems, which are shaped by the process of globalization and the emergence of new transnational threats on the other. ${ }^{36}$

To effectively address contemporary international law problems at their sources, international law, particularly international environmental law, has shifted from independent regulation above the national state to influencing domestic actors, who are the primary causes of the problems, and their states' government policies and institutions, the

34 Article 38 (1) (a-c) of the Statute of International Court of Justice lists treaties, customs international law, and general principles of international law recognized by civilized nations as the main sources of international law. Sub-paragraph (d) of the same article lists judicial decisions and the teachings of the most highly qualified publicists as the secondary sources. On sources of international environmental law see generally Patricia Birnie, Alan Boyle, and Catherine Redgwell (n 10) 14-42.

35 It is important to also mention that although the few Nigerian cases and legislations analysed do not allow for greater objectivity and generalization in the statistical sense to support the first part of the argument put forward in this article, the data analysis approach adopted allows for detailed examination and understanding of the legal status of sustainable development in such cases and legislation as well as provides methodology strategy for ascertaining its legal status in other cases and laws. See Lindsay Prior, Using Documents in Social Research (SAGE Publications Ltd. 2003) 153.

36 A Slaughter, A. and W Burke-White, 'The Future of International Law is Domestic (or, The European Way of Law)' (2006) 47 (2) Harvard International Law Journal 327, 327-328. 
majority of which lack the political will and capacity to address the problems. ${ }^{37}$ There is no doubt that the legal status of sustainable development in international environmental law will influence how it is domesticated - implementation and enforcement - into the Nigerian environmental law, as well as the compliance behaviour of the federal and state governments, among other relevant stakeholders.

This article consists of six sections. The section following the introduction defines sustainable development and adumbrates on its historical development. Section 3 presents secondary data on the parlous state of the environment. A number of factors are responsible for this predicament but the section emphasizes the legal status or the weight assigned to sustainable development. Section 4 ascertains the status of sustainable development in the National Policy on the Environment and the National Environmental Standards and Regulation Enforcement Agency (Establishment) Act 2007 No. 25, ${ }^{38}$ as well as the National Environmental (Desertification Control and Drought Mitigation) Regulations, $2011^{39}$ and National Environmental (Wetland, River Banks and Lake Shores Protection) Regulations, $2009^{40}$ made under the NESREA Act.

This section also examines the perspectives of the Nigerian courts on sustainable development. The penultimate section dwells on how to enhance the implementation and enforcement of sustainable development in the Nigerian environmental law. The last section of this article concludes by reiterating the need to integrate sustainable development into the 1999 Constitution as an essential aspect of the right to life and other relevant constitutional environmental provisions, as well as transfer section 20 of the 1999 Constitution to Chapter IV of the Constitution.

\section{MEANING AND HISTORICAL DEVELOPMENT OF SUSTAINABLE DEVELOPIMENT}

The definition of sustainable development is complex and unclear. ${ }^{41}$

37 ibid 331.

38 Hereinafter referred to as NESREA Act. This Act establishes the National Environmental Standards and Regulation Enforcement Agency hereinafter referred to as 'The Agency'. See Section 1(1), NESREA Act 2007.

39 Hereinafter referred to as Desertification Control and Drought Mitigation Regulations.

40 Wetland, River Banks and Lake Shores Protection Regulations.

41 Patricia Birnie, Alan Boyle, and Catherine Redgwell (n 10) 54. 
Its original conceptualization is defined in Our Common Future (otherwise known as the Brundtland Report) as:

... development that meets the needs of the present without compromising the ability of future generations to meet their own needs. The term contains within it two key concepts: the concepts of 'needs,' in particular the essential needs of the world's poor, to which overriding priority should be given; and the idea of limitations imposed by the state of technology and social organization on the environment's ability to meet present and future needs..$^{42}$

Put simply, the fundamental elements of sustainable development are (i) equity towards future generations or passing a clean and healthy environment to future generations, (ii) equity within our generation or addressing the global economic inequalities, and (iii) integrating environmental protection into development processes. ${ }^{43}$ Even though the concepts of integrating environmental protection into development policies and intergenerational equity constitute the substratum of the rights or obligations equation in any legal framework of sustainable development, poverty alleviation is also important, especially when setting obligations for developing states. ${ }^{44}$

Before sustainable development gained popularity in Our Common Future by the World Commission on Environment and Development

42 The World Commission on Environment and Development, Our Common Future (Oxford University Press 1987) 43Bratspies RM (n 9) 364.

43 Shyami, F. Puvimanasinghe, 'Development, Environment and the Human Dimension: Reflections on the Role of Law and Policy in the Third World, with Particular Reference to South Asia' (2000) 12 Sri Lanka Journal of International Law 35, 37 and 38; Emmanuel E. Okon, 'The Environmental Perspective in 1999 Nigerian Constitution' (2003) 5 (4) Environmental Law Review 256.

44 On basic principles of intergenerational equity see Edith Brown Weiss, 'Intergenerational Equity: A Legal Framework for Global Environmental Change' in Edith Brown Weiss (ed), Environmental Change and International Law (United Nations University Press 1992), 385, 398-397. Paragraph 5 of the 2002 Johannesburg Declaration on Sustainable Development, which states that 'we assume a collective responsibility to advance and strengthen the interdependent and mutually reinforcing pillars of sustainable development - economic development, social development and environmental development - at the local, national, regional and global levels'. The three core areas are reduced to the specifics or basic elements in Paragraph 4 of Part 1, which deals with 'Our Common Vision' in The Future We Want, UNGA Resolution A/66/L.56 of 24 July 2012. <www.un.org/en/sustainablefuture/> accessed 10 January 2016. 
(WCED) in 1987, other international instruments such as the 1946 International Convention for the Regulation of Whaling, ${ }^{45} 1972$ Stockholm Declaration, ${ }^{46}$ the UN Charter of Economic Rights and Duties of States ${ }^{47}$ and the World Conservation Strategy: Living Resource Conservation for Sustainable Development (WCS) ${ }^{48}$ contained some elements of sustainable development. Sustainable development underpins the five environmental instruments adopted at the United Nations Conference on Environment and Development, ${ }^{49}$ but its basic characteristics and implementation targets are outlined in the 1992 Rio Declaration and Agenda 21 respectively. ${ }^{50}$

45 The preamble of the Convention provides as follow 'recognizing the interest of the nations of the world in safeguarding for future generations the great natural resources represented by the whales' stocks' (Italics is mine)

46 See particularly, Principle 1 of the 1972 Stockholm Declaration, which states, among other things, that man bears a solemn responsibility to protect and improve the environment for present and future generations. <http:// sitemaker. umich.edu/drwcasebook/files/stockholm_declaration.pdf $>$ accessed 26 January 2015.

47 UN General Assembly Res. 3281 (XXIX), UN GAOR, 29th Sess., Supp. No. 31 (1974) 50. Reproduced in (1975) 14 I.L.M. 251. Article 30 provides that the protection, preservation and enhancement of the environment for the present and future generations is the responsibility of all states and urged states to establish their own environmental and development policies in conformity with such responsibility.

48 As a matter of fact, the introduction of the WCS deals with living resources conservation for sustainable development and Paragraph 4 of the introduction defines conservation as the management of human use of the biosphere so that it may yield the greatest sustainable benefit to present generation while maintaining its potential to meet the needs and aspiration of future generations.

49 The instruments are (1) Rio Declaration, (2) Agenda 21, (3) Convention on Biological Diversity, (4) United Nations Framework Convention on Climate Change (UNFCCC), and (5) Principles/Elements of the Statement of Principles for a Global Consensus on the Management, Conservation and Sustainable Development of All Types of Forests.

50 For Rio declaration see particularly Principle 3 which states that 'the right to development must be fulfilled so as to equitably meet developmental and environmental needs of present and future generations' and Principle 4 which states that in order to achieve sustainable development, environmental protection shall constitute an integral part of the development process and cannot be considered in isolation of it'. For Agenda 21 see para 1.1 of Chapter 1, which states: 'humanity stands at a defining moment in history. We are confronted with a perpetuation of disparities between and within nations, a worsening of poverty, hunger, ill health and illiteracy, and the continuing deterioration of the ecosystems on which we depend for our well-being. However, integration of environment and development concerns and greater attention to them will lead to the fulfilment of basic needs, improved living standards for all, better protected and managed ecosystems and a safer, more prosperous future ...' 
The 2000 United Nations Millennium Declaration (UNMD) identified among others that prudence must be shown in the management of all living species and natural resources, in accordance with the precepts of sustainable development. Indeed, the 7th Millennium Development Goal (MDG 7) urged states to integrate the principles of sustainable development into their development policies and programmes and reverse the loss of environmental resources.

The Johannesburg Declaration on Sustainable Development and World Summit on Sustainable Development (WSSD) Plan of Implementation adopted at 2002 WSSD reaffirmed the commitment of states to sustainable development. During the Rio +20 Conference held in Rio de Janeiro, the Heads of State and Government and highlevel representatives also renewed their commitment in The Future We Want to sustainable development and to ensuring the promotion of an economically, socially and environmentally sustainable future for our planet and for present and future generations. ${ }^{51}$

A new aeon in the chequered history of sustainable development occurred on 25 September 2015 when the United Nations General Assembly (UNGA) adopted Resolution A/RES/70/1 on transforming our world: the 2030 Agenda for Sustainable Development. ${ }^{52}$ The resolution announced 17 Sustainable Development Goals and 169 targets, which will stimulate action over the next 15 years in areas of critical importance for humanity and the planet. The goals and targets are integrated and indivisible and balance the three dimensions of sustainable development: the economic, social and environmental. ${ }^{53}$

In Nigeria, the adoption of the National Policy on the Environment and the Objectives and Strategies for Nigeria's Agenda 21 introduced sustainable development practices and policies into environmental governance in the country. Both instruments aim at integrating environment into development planning at all levels of government

51 See generally Parts 1 and 11 of The Future We Want, which respectively deal with the common visions and commitments to implement all the principles and plan of implementation adopted by the UNGA on sustainable development. UNGA Resolution A/66/L.56 of 24 July 2012. < http://daccess-dds-ny.un.org/ doc/UNDOC/LTD/N12/436/88/PDF/N1243688.pdf?OpenElement > accessed August 02, 2016.

52 UNGA Resolution A/RES/70/1 of 25 September 2016 <http://www.un.org/ en/ga/search/view_doc.asp?symbol=A/RES/70/1> accessed 14 August 2016.

53 ibid. 
and the private sector. As sustainable development has become the bedrock of Nigerian environmental law, it is all the more necessary to ascertain its legal status and how best to enhance its implementation and enforcement.

\section{LINKAGE BETWEEN DEPLORABLE STATE OF THE ENVIRONMENT AND LEGAL STATUS OF SUSTAINABLE DEVELOPIMENT}

The Millennium Development Goal Report 2005 (2005 MDG) on the progress made towards achieving the MDGs states that most countries are committed to the principles of sustainable development and have incorporated them into their national policies and strategies. ${ }^{54}$ This is an indication of a general state practice to integrate sustainable development into national policies and strategies. Regrettably, the 2005 MDG went further to state that this has not resulted in sufficient progress to reverse the loss of the world's environmental resources. The most recent Millennium Development Goals' Report $2015^{55}$ reveals that efforts to ensure global environmental sustainability have shown mixed results throughout the last 15 years. Certainly, more people now have access to improved source of water and sanitation facilities, consumption of ozone-depleting substances have reduced by 98 per cent, the proportion of urban population living in slums in the developing regions has reduced from 39 per cent in 2000 to 30 per cent in 2014, and protected areas of terrestrial and inland waters have increased to 15.2 per cent while 8.4 per cent of coastal marine areas under national jurisdiction have come under protection. These notwithstanding, much work remains for the post-2015 development agenda considering the core environmental problems such as climate change, overexploitation of marine living resources, threatening aquatic ecosystems and livelihoods, protection of only 0.25 per cent of the high sea areas, deforestation, increase in the absolute number of urban residents living in slums, water and food insecurity, and risk of extinction of many plant and animal species. ${ }^{56}$

54 United Nations, Millennium Development Goals Report 2005 (United Nations 2005) 30.

55 United Nations, The Millennium Development Goals Report 2015 (United Nations 2015) $52-61$.

56 ibid. 
The implication of all these is that the integration of sustainable development into national policies and programmes has not been very effective, given the extent of environmental problems solved. This is attributed to a number of reasons, one of which, arguably, is the legal status of sustainable development or the legal weight assigned to it. Contrary to this perspective, Judge Trindade in his Separate Opinion in Pulp Mills on the River Uruguay (Argentina $v$ Uruguay) ${ }^{57}$ argues that 'the attitude of some of contemporary expert writings trying to see if a given principle, such as sustainable development, has attained the status of a norm of customary international law, or has been recognized in conventional international law, simply misses the point, and is conceptually flawed'. ${ }^{58}$

He cited as an example the brief invocation, in passim, of the principle of good faith in the majority judgment in the Pulp Mills case (in relation to the operation of the mechanism of cooperation under the 1975 Statute of the River of Uruguay ${ }^{59}$ ) and immediately linking such brief invocation of the principle to customary international law, as if general principles were subsumed under customary international law. ${ }^{60}$ Paradoxically, the lengthy discourse of Judge Trindade on general principles of International Environmental Law, which includes sustainable development, basically establishes the status of general principles. For instance, Judge Trindade is of the opinion that the principle of good faith occupies a key position in international law and all legal systems, providing them all with an ethical basis, and surely standing above the positive law. The phrases or words such as standing ineluctably at a superior level, ${ }^{61}$ pre-eminent character, ${ }^{62}$ key position ${ }^{63}$ and standing above ${ }^{64}$ which Judge Trindade or other authors referred to by him used in describing general principles of law connote power relations between general principles and rule of custom or norm of law. Probably, a little oversight on the part of Judge Trindade, he does

57 2010] Judgment, I.C.J. Reports 14. This case is hereinafter referred to as the Pulp Mills case.

58 ibid [17] 132.

59 For online text of the Statute see $<$ http://legal.un.org/ilc/texts/instruments/ english/conventions/8_3_1997.pdf $>$ accessed 7 March 2016.

60 [2010] Judgment, I.C.J. Reports 14 [145] and [175] 191.

61 ibid [39] 141.

62 ibid [41].

63 ibid [178] 193.

64 ibid. 
not inform the parties in the case, his fellow Judges, and readership, on the exact power relationship existing between general principles and rule of custom or norm of law and whether the character of a general principle could for whatever reason change.

In fact, the existence of a hierarchy in international and municipal law cannot be denied. This has been the case with international law since the introduction of the concept of jus cogens into Article 53 of the Vienna Convention on the Law of Treaties 1969, ${ }^{65}$ Article 103 of the United Nations Charter, ${ }^{66}$ which gives precedence to obligations under the Charter over commitment under other treaties, and obligations erga omnes, ${ }^{67}$ which is closely bound up with that of jus cogens. ${ }^{68}$

65 Article 53 of the Vienna Convention on the Law of Treaties 1969 provides that 'A treaty is void if, at the time of its conclusion, it conflicts with a peremptory norm of general international law. For the purposes of the present Convention, a peremptory norm of general international law is a norm accepted and recognized by the international community of States as a whole as a norm from which no derogation is permitted and which can be modified only by a subsequent norm of general international law having the same character'.

66 Article 103 of the United Nations Charter provides that 'In the event of a conflict between the obligations of the Members of the United Nations under the present Charter and their obligations under any other international agreement, their obligations under the present Charter shall prevail'.

67 International law has established a category of erga omnes (Latin word meaning 'toward all') obligations, which apply to all states. Whereas in ordinary obligations the defaulting state bears responsibility toward particular interested states (e.g., other parties to the treaty that has been breached). See International Law: Hierarchies of Sources and Norms, Encyclopedia Britannica, $<$ www.britannica.com/topic/erga-omnes> accessed March 2, 2016.

68 Obligatioerga omnes pertains to the legal implications arising out of a certain crime's characterization as jus cogens. International crimes that rise to the level of jus cogens constitute obligatio erga omnes which are inderogable. Legal obligations which arise from the higher status of such crimes include the duty to prosecute or extradite, the non- applicability of statutes of limitations for such crimes, the non-applicability of any immunities up to and including Heads of State, the non-applicability of the defense of 'obedience to superior orders' (save as mitigation of sentence), the universal application of these obligations whether in time of peace or war, their non-derogation under 'states of emergency,' and universal jurisdiction over perpetrators of such crimes. M Cherif Bassiouni, 'International Crimes;Jus Cogens and Obligatio Erga Omnes' (1997) 59 (4)Law and Contemporary Problems 63. See generally Koskenniemi, M (n 2) 566 and Ulrich Beyerlin, 'Different Types of Norms in International Environmental Law Policies, Principles and Rules' in Daniel Bodansky, Jutta Brunnée, and Ellen Hey (eds), The Oxford Handbook of International Environmental Law (Oxford University Press 2007), 425. Regrettable, presently no international environmental rule is classified as jus cogens or has created obligation erga omnes. See generally Environmental Investigation Agency, Environmental Crime: 
Similarly, the use of concepts such as fundamental law, the supremacy of the constitution or basic norm in Kelson's Pure Theory of Law in municipal law discourses strongly suggests the existence of a hierarchy of municipal laws. ${ }^{69}$ In Attorney-General Abia State v Attorney General Federation, ${ }^{70}$ the Supreme Court of Nigeria (SCN), referring to Section 1(1) and 1(2) of the 1999 Constitution explained the hierarchy of Nigerian laws thus:

The Constitution is what is called the groundnorm and the fundamental law of the land. All other legislations in the land take their hierarchy from the provisions of the Constitution. By the provisions of the Constitution, the laws made by the National Assembly come next to the Constitution; followed by those made by the House of Assembly of a State. By virtue of section 1(1) of the Constitution, the provisions of the Constitution take precedence over any law enacted by the National Assembly even though the National Assembly has the power to amend the Constitution itself. ${ }^{71}$

A threat to our future, (Environmental Investigation Agency 2008); Paul B Stephan, 'The Political Economy of Jus Cogen' (2011) 14(4) Vanderbilt Journal of International Law 1073, 1081-1103.

69 Kelsen H, General Theory of Law and State (Anders Wedberg (tr) Russell \& Russell 1961), 123-124. According to Kelsen, 'The analysis of law, which reveals the dynamic character of this normative system and the function of the basic norm, also exposes a further peculiarity of law: Law regulates its own creation inasmuch as one legal norm determines the way in which another norm is created, and also, to some extent, the content of that norm. Since a legal norm is valid because it is created in a way determined by another legal norm, the latter is the reason of validity of the former. The relation between the norm regulating the creation of another norm and this other norm may be presented as a relationship of super- and sub-ordination ... The norm determining the creation of another norm is the superior, the norm created according to this regulation, the inferior norm. The legal order ... is therefore not a system of norms coordinating to each other, standing, so to speak, side by side on the same level, but a hierarchy of different levels of norms. The unity of these norms is constituted by the fact that the creation of one norm - the lower one is determined by another - the higher - the creation of which is still determined by a still higher norm, and that this regressus is terminated by a highest, the basic norm which, being the supreme reason of validity of the whole legal order, constitutes its unity'. ibid124.

70 [2002] 6 NWLR (Pt 763) 264.

71 ibid 479-480. See also Daniel Orhiunu v Federal Republic of Nigeria [2004] LPELR-5880 (CA) Per Galadima JCA 12-13 [F-B]. 
Importantly too, there is no doubt that graduation of norms is a necessary feature of international law and municipal legal system. ${ }^{72}$ For instance, in the North Sea Continental Shelf Cases, ${ }^{73}$ the ICJ recognized the fact that a rule while only conventional or contractual in its origin can pass into the general corpus of international law. ${ }^{74}$ In Nigeria, the decisions of the SCN on some of the provisions of Chapter II of the 1999 Constitution provide a good example of graduation of norms at the municipal level. Chapter II of the 1999 Constitution deals with the Fundamental Objectives and Directive Principles of State Policy. ${ }^{75}$ Its cardinal characteristic is its non-justiciability by virtue of section 6(6)(c) of the 1999 Constitution, which provides to the effect that judicial powers shall not, except as otherwise provided in the Constitution, extend to any issue or question as to whether any question, act of omission by any authority or person, any law or any judicial decision is in conformity with Chapter II.

In Chief Adebiyi Olafisoye v Federal Republic of Nigeria ${ }^{76}$ the SCN decided that the provisions of Chapter II of the 1999 Constitution are justiciable if the National Assembly legislates on them based on the provisions of Item 60(a) of the Exclusive Legislative List of the Second Schedule to the 1999 Constitution. ${ }^{77}$ This is exactly the implication of

72 Weiler, J. H. H. and Andrea L Paulus, 'The Structure of Change in International Law or Is There a Hierarchy of Norms in International Law' (1997) 8 (4)European Journal of International Law 545, 561. Dupuy puts it more succinctly thus 'the migration of an obligation from the restricted scope of a treaty, limited to a particular group of states, to that of general international law is neither theoretically nor technically impossible'. Pierre-Marie Dupuy, 'Formation of Customary International Law and General Principles' in Daniel Bodansky, Jutta Brunnée, and Ellen Hey (eds), The Oxford Handbook of International Environmental Law (Oxford University Press 2007) 449, 457.

73 North Sea Continental Shelf, Judgment, (1969) ICJ Report 3.

74 ibid. See generally [70-73].

75 Chapter II of the Constitution was first introduced in the 1979 Constitution of the Federal Republic of Nigeria. The 1979 Constitution had the following fundamental objectives and directive principles: political objectives (s. 15), economic objectives (s. 16), social objectives (s. 17), educational objectives (s. 18), foreign policy objectives (s. 19), directive on Nigerian culture (s. 20). Obligation of the mass media (s. 21) and national ethic (s. 22), The 1999 Constitution added only the environmental objectives (s. 20) and duties of the citizen (s. 24) to the fundamental objectives and directive principles contained in the 1979 Constitution.

76 [2004] 4 NWLR [Pt 864] 580.

77 The sub-item provides: 'The establishment and regulation of authorities for the Federation or any part thereof - (a) to promote and enforce the observance of the Fundamental Objectives and Directive Principles contained in this Constitution'. 
enactment of the Corrupt Practices and other Related Offences Act 2000 (ICPC Act) wherein the National Assembly gave effect to section 15(5) of the 1999 Constitution, which provides that the state shall abolish all corrupt practices and abuse of power. ${ }^{78}$ With the enactment of the NESREA Act, which under section 1(1) established the National Environmental Standards and Regulations Enforcement Agency (Agency) and in section 1(2) vests the Agency with the power to enforce environmental standards, regulation, rules, policies and guidelines, one cannot rightly argue again that environmental obligation of the State under section 20 of the 1999 Constitution is not justiciable. In effect, an ordinarily legal postulate on the environment entrenched in section 20 of the 1999 Constitution has transmuted to a legal obligation or duty by virtue of section 1(1) and (2) of the NESREA Act.

\section{LEGAL STATUS OF SUSTAINABLE DEVELOPMENT IN THE NIGERIAN ENVIRONMENTAL LAW}

It is easy for any environmentalist to claim that sustainable development has been integrated into the Nigerian environmental law, but determining its legal status or weight may not be as easy as expected. The 1999 Constitution contains environmental provisions, but there is no specific provision on sustainable development. Since it is not possible to examine the legal status of sustainable development in the plethora of Nigerian legislation on the environment, ${ }^{79}$ the focus here is on the National Policy on Environment and the NESREA Act because of their overarching effect on all aspects of the environment. This section also examines the status of sustainable development in the

78 Attorney-General of Ondo State v Attorney-General of the Federation and Ors [2002] 9 NWLR (Pt. 772) 222, other provisions of the 1999 Constitution which the SCN considered in this case are ss. 4(2) and 13 as well as item 60(a) on the Exclusive Legislative List. For similar judgment of the SCN see AttorneyGeneral of Lagos State v Attorney-General of the Federation \& 35 Ors [2003] 12 NWLR [Pt. 833] 241 and Chief Adebiyi Olafisoye v Federal Republic of Nigeria [2004] 4 NWLR [Pt 864] 580. Generally, see Emmanuel E. Okon, 'The Constitution and the Protection of the Environment in Nigeria' in Azinge Epiphany, and Adedeji. Adekunle, (eds.) Administration of Justice and Good Governance in Nigeria: Essays in Honour of Hon. Justice A. I. Katsina-Alu, GCON Chief Justice of Nigeria (NIALS 2011) 323-369.

79 Emmanuel E Okon 'The Constitution and the Protection of the Environment in Nigeria' (n 78) 333-334. 
Desertification Control and Drought Mitigation Regulations and the Wetland, River Banks and Lake Shores Protection Regulations made under the NESREA Act.

\section{(i) National Policy on the Environment}

The first National Policy on the Environment (NPE) launched by the Federal Government on 27 November 1989 was drastically reviewed in 1999 with the aim of incorporating new concepts, principles, and changes into the environmental governance adopted in the Rio Declaration on Environment and Development and the other 1992 Rio instruments. Paragraph 2 of the NPE states in general term that the goal of the NPE is to achieve sustainable development in Nigeria. ${ }^{80}$ Paragraph 3.0 of the NPE categorically states that the NPE is basically a programme of actions rooted in a conceptual frame within which the linkages between environmental problems on the one hand and their causes, effects, and solutions, on the other hand, can be discerned.

Describing the policy as a programme of action agrees with most dictionary definitions of policy as a definite course or method of action selected from among alternatives and in light of given conditions to guide and determine present and future decisions. ${ }^{81}$ Understanding policy in this context is also not too different from Dworkin's definition of policy as that standard that sets out a goal to be reached, generally an improvement in some economic, political, or social feature of the community. ${ }^{82}$ The social feature includes the environment.

By expressing sustainable development as a programme of actions in the NPE it is at best a soft law. This must have informed the Federal government's decision to clearly list in Paragraph 3.0(a-e) of the NPE the different ways of achieving the policy and by extension sustainable development. One of the ways is to give it legal clothing. This is the basis of Paragraph 3.0(d) of the NPE which states thus 'enactment of necessary legal instruments designed to strengthen the activities and strategies recommended by this policy'. To actualize the provision Paragraph 3.0(d) of the NPE, the NESREA Act and other environmental

80 For the specifics of the policy see paragraph 2(a-e) of the NPE.

81 Merriam-Webster Dictionary of English Language (Since 1828) <www.merriamwebster.com/dictionary/policy> accessed 12 March 2016.

82 Ronald M. Dorwkin, The Model of Rules. Yale Law School Legal Scholarship Repository, Faculty Scholarship Series, Paper 3609 (1967) 23. <http:// digitalcommons.law.yale.edu,/fss_papers/3609> accessed 12 March 2016. 
legislation were enacted. Section 7(a) of the NESREA Act stipulates as part of the Agency's functions the enforcement of policies (NPE inclusive) on environmental matters.

\section{(ii) NESREA Act}

The legal status of sustainable development in the NESREA Act will ordinarily depend on whether it is placed in the recital or the operative part. Incidentally, the drafters and legislators of modern statutes have jettisoned the use of preambles and recitals except in Constitutions and in rare cases when domesticating treaties. In line with this new trend, the NESREA Act does not have a recital. ${ }^{83}$ This implies that any provision on sustainable development will be in the operative part of the Act. In that case, the status of sustainable development will depend on whether it is expressed in a general or specific mandatory language. Section 1(2) of the NESREA Act provides that the Agency shall have, among others things, the responsibility for 'the .... and sustainable development of Nigeria's natural resources ... in general'. Going by this provision, sustainable development is expressed as a rule of law, which creates a duty for the Agency to ensure its enforcement, particularly when a combined effect of sections 2(a) and 7(a) the NESREA Act provides that the Agency shall be the enforcement agency for the purpose of ensuring compliance with the sustainable development of Nigeria's natural resources.

The crucial question that begs for answer then is whether sustainable development is expressed in section 1(2) of the NESREA Act in general or specific terms bearing in mind that neither section 37 nor any other section of the NESREA Act specifically defines 'sustainable development'. Regrettably, the National Assembly did not adopt its common meaning as publicized in the Brundtland Report. Meanwhile, as shown in the introductory part of this article, there is still an unresolved controversy regarding the exact meaning of sustainable development. As it stands, in the NESREA Act, sustainable development is the rule of law but expressed in general terms. Considering its diverse meanings, it has some elements of uncertainty. That reduces its rule potency thus pushing it to the side of a general principle or principle of law. According to Dworkin, a principle means a standard that is to be observed, not because it will advance or secure an economic, political,

83 See also the National Park Service Act 1999. 
or social situation deemed desirable, but because it is a requirement of justice or fairness or some other dimension of morality. On the other hand, rules are applicable 'in an all-or-nothing' standards.

In Duncan's perspective, the two great social virtues of formally realizable rules, as opposed to standards or principles, are the restraint of official arbitrariness and certainty. ${ }^{84}$ The two are distinct but overlapping. Official arbitrariness means the sub rosa use of the criteria of decision that are inappropriate given the underlying purpose of the rule. These range from corruption to political bias. Certainty, on the other hand, is valued for its effect on the citizenry: if private actors can know in advance the incidence of official intervention, they will adjust their activities in advance to take account of them. From the state, this increases the likelihood that private activity will follow the desired pattern. ${ }^{85}$

Indeed, the power of the Agency to enforce sustainable development of Nigeria's natural resources could be hindered by nonlegal factors, especially politics and economics. These are the major reasons why the NESREA Act is very explicit that the Agency's functions do not extend to oil and gas sector. ${ }^{86}$ Uncertainty in the meaning of sustainable development means that both the Agency and individuals or organizations it may prosecute can raise conflicting claims as well as resort to factors not contemplated by the Agency. For instance, the requirement of impact assessment, which is more of a procedural element of sustainable development, could be an issue of conflict. Meanwhile, the effectiveness of substantive legal provisions to protect the environment hinges upon accompanying procedural provisions to facilitate their enforcement. ${ }^{87}$

Ascertaining the legal status of sustainable development under the NESREA Act is further complicated when viewed from the perspective that sustainability of natural resources or the environment is expressed as sometimes an objective, other times a purpose or a principle in

84 Kennedy Duncan, 'Form and Substance in Private Law Adjudication' (1976) 89Harv L Rev 1685.

85 ibid 1688-1689.

86 For instance, see sections $7(\mathrm{~g}), 8(\mathrm{~g})(\mathrm{k})(\mathrm{l})(\mathrm{m})$ and $(\mathrm{n})$, and 30(4) of the NESREA Act.

87 Patricia Kameri-Mbote, and Collins Odote, 'Courts as Champions of Sustainable Development: Lessons from East Africa' (2009-2010) 10Sustainable Dev L \& Pol'y 31-38 and 83-84, 35. 
some of the regulations made under the NESREA Act. For instance, Regulation 2 of the National Environmental (Desertification Control and Drought Mitigation) Regulations, 2011 expressly states that the objectives of Part 1 (General Provisions on Desertification Control) of the Regulations are to...

(c) encourage the sustainable use of fuelwood through the use of more efficient and energy saving devices with a view to encouraging their wider use and adoption at all levels...

(g) ensure sustainable agriculture and range management practices, improved animal husbandry and management of water resources in the desertification prone areas with a view to achieving sustainable livelihood, poverty reduction and wealth creation; through introduction of modern and affordable production technologies to resource poor farming communities.

In contrast, Regulation 3 of the National Environmental (Wetland, River Banks and Lake Shores Protection) Regulations, 2009 provides that

'The following principles shall be observed in regulating all wetlands:

(a) Wetland resources shall be utilised in a sustainable manner compatible with the continued presence of wetlands and their hydrological functions and services; ${ }^{; 88}$

The interesting aspect of expressing sustainability as objectives or principle in the two mentioned Regulations is that it is not expressed as a political statement. Rather, it is expressed in a precise manner and in the form of obligatory statements among other concrete lists of measurable criteria by which the effectiveness of the NESREA Act and the respective Regulations are to the assessed, thus offering the legislature a unique opportunity to take a degree of control over the executive's post-legislative conduct.

\section{Nigeria Case Law}

Regrettably, a qualitative content analysis of Law Pavilion Online reveals that sustainable development is neither specifically nor directly

88 Note that Regulation 3(b-d) does not make express reference to 'sustainability' or 'sustainable development' of wetland resources. 
integrated into any of the Nigerian courts' jurisprudence. As a matter of fact, it is only in Oronto Douglas v Shell Petroleum Development Coy $L t d \& O r S^{89}$ that Musdapher JCA while delivering the leading judgment of the Court of Appeal used a closed term 'sustainable environment' when describing the Plaintiff/Appellant as '... an activist in the protection of the environment. He is actively involved in the protection of the environmental rights promotion of waste management and generally save and sustainable environment'. ${ }^{90}$

The first time serious reference was made to sustainable development by the Nigerian courts was in Attorney-General of Lagos State v Attorney-General of the Federation \& 35 Ors. ${ }^{91}$ In this case, Lagos State challenged the constitutionality of the Federal Government relying on the Nigerian Urban and Regional Planning Act $1992^{92}$ to interfere with and make incursions into the arrangement of the Lagos State Government in town and country planning matters notwithstanding its own Town and Country Planning Laws. One of the major issues canvassed by counsels on both side of the case was whether the Federal Government might rely on the NURPA to legislate for the states on urban and regional planning pursuant to section 20 of the 1999 Constitution. Section 20 of the 1999 Constitution mandates the state to protect and improve the environment and safeguard the water, air and land, forest and wildlife of Nigeria.

It was in an attempt to address this issue that sustainable development crept into the jurisprudence of the SCN without the court expatiating or ascertaining its legal status since that was not one of the issues canvassed before it. Uwaifo JSC who delivered the lead judgment referred to the argument of the Attorney-General of Anambra State in support of the plaintiff thus, 'She argues that legislation provided the legal framework for the improvement of policies, goals and objectives pertaining to environmental protection, natural resources conservation and sustainable development'. ${ }^{93}$ More importantly, Ejiwunmi JSC agreed with Uwaifo JSC on the distinction made by Mr Paul Usoro, Counsel to Niger State, the 26th Defendant, regarding the relationship between urban and regional planning and environment

89 [1998] LPELR-6457 (CA).

90 ibid.

91 [2003] 6 SC 24.

92 Formerly known as Decree No 88 of 1992 . Hereinafter referred to as NURPA.

93 Attorney-General of Lagos State (n 91) 41. 
thus:

It is of course correct and imperative that urban and regional planning must take account of environmental factors and seek always to protect and develop Nigeria's environment and conserve its biodiversity and promote the sustainable development of Nigeria's natural resources. However, it is our submission that the two roles - urban and regional planning and management of the environment - are distinct and separate under the constitution and cannot and should not be merged. ${ }^{94}$

On the other hand, Ayoola JSC took a different stand that planning and environment regulation may at their core be distinct activities, it cannot be denied that these activities may overlap. Quoting from a passage in Halsbury's Laws of England (4th Edition) Vol. 46, para 1 Ayoola JSC said 'the town and country planning system is designed to regulate the development and use of land in the public interest; and it is an important instrument for protecting and enhancing the environment in town and country... ${ }^{95}$

From the perspective of Ayoola JSC, one can argue that the use of town and country planning for regulation of development and protection of environment makes it an effective regulatory tool (just like environmental impact assessment) that ensures the integration of environmental concerns into development projects, which is the threshold of sustainable development. The truth is whether viewed from the perspective of the phrase 'designed to regulate the development and use of land ...' or 'must take into account environmental law' sustainable development is presented as a procedural rule created albeit through case law.

In summary, the above statutory and case law analysis reveals that sustainable development is a rule of law in Nigeria. Statutorily, for example, it is expressed in the Desertification and Drought Regulations, and the Wetland, River Banks and Lake Shores Regulations as determinable, measurable and achievable objectives and principle respectively. It is also expressed with the same characteristics in the SCN's decision in Attorney-General of Lagos State v Attorney-General of the Federation \& 35 Ors, ${ }^{96}$ but as a procedural case law rule. Of course,

94 ibid 108.

95 ibid 175. 
as an ordinary rule of law it can only create ordinary rights and obligations.

This legal position will not change even if one takes into consideration the SCN's decisions in Attorney-General of Ondo State v Attorney-General of the Federation and $\mathrm{Ors}^{97}$ and Chief Adebiyi Olafisoye $\mathrm{v}$ Federal Republic of Nigeria,${ }^{98}$ which makes the constitutional provision in section 20 of the 1999 Constitution justiciable by an ordinary law created by the National Assembly or existing Federal Government legislation on the environment. ${ }^{99}$ As an ordinary rule of law, the courts will enforce environmental rights, which include sustainable development, in the same manner as any other ordinary right derived from other federal legislation.

\section{EFFECTIVE IMPLEMENTATION AND ENFORCEMENT OF SUSTAINABLE DEVELOPMENT IN NIGERIA}

The level of compliance with the environmental law in Nigeria is low, and all tiers of government, as well as their investment partners, are the major culprits. Meanwhile, as noted earlier, a combined effect of sections 1(2)(a) and 7(a) of the NESREA Act vests in the Agency the power to enforce and ensure compliance with environmental standards, regulation, rules, laws, policies and guidelines. ${ }^{100}$ Of course, this includes ensuring compliance with the sustainable development of Nigeria's natural resources. Notwithstanding the fact that the uncertainty in the language used to integrate sustainable development into the NESREA Act has been addressed by the specific obligatory language used in the Desertification and Drought Regulations, and the Wetland, River Banks and Lake Shores Regulations, enforcement of sustainable development of Nigeria's natural resources by the Agency is still poor.

96 Attorney-General of Lagos State (n 91).

97 [2002] 9 NWLR (Pt. 772) 222.

98 (2004) 4 NWLR (Pt 864) 580.

99 or the detailed analysis of the SCN's judgment in these cases see generally Emmanuel E. Okon, 'The Constitution and the Protection of the Environment in Nigeria' (n 78); Emmanuel E Okon, 'The Environmental Perspective in 1999 Nigerian Constitution' (n 43).

100 Emmanuel E. Okon, 'The Residue of Unitary System in the Regulation of the Environment in Nigeria' in Deji Olanrewaju (ed) Law and Its Leeway: Essays in Honour of Emeritus Professor Isaac Oluwole Agbede (Gem Communications Resources Limited 2014) 307, 333. 
Regrettably, since only the Agency has the power to enforce environmental legislation or policies, individuals, non-governmental organizations (NGOs) and local communities have no locus standi to bring claims for the enforcement for sustainable development, especially the integration of environmental concerns into developmental projects. ${ }^{101}$ This has continued to be a clog in the wheel of environment justice and has been the main reason why some Nigerians have sought environmental justice outside Nigeria in order to avoid the locus standi condition that must be met by all litigants. ${ }^{102}$

These challenges must be addressed to enhance the implementation and enforcement of sustainable development in Nigerian environment law. First, the National Assembly should integrate sustainable development into the 1999 Constitution by expressing it in precise and direct terms as a constitutional rule and as an essential element to the right of life of present and future generations. The National Conference 2014 recognized this fact when it noted in its recommendations of constitutional provisions on the environment that 'the vital need to preserve the integrity of the Nigerian environment and thus secure its sustainability for present and future generations requires clear and direct stipulations in the Nigerian Constitution'. ${ }^{103}$

To achieve this same objective, the National Assembly should expand the scope of existing constitutional right to life in section 33(1) to include the right to sustainable development. Section 33(1) of the 1999 Constitution, which is part of Chapter IV dealing with fundamental human rights, provides that 'Every person has a right to life, and no one shall be deprived intentionally of his life, save in execution of the sentence of a court in respect of a criminal offence of which he has been found guilty in Nigeria'. Because the Constitution is a living document, the words 'Every Person' used in section 33(1) of the 1999 Constitution should be interpreted broadly to include present and

101 The term locus standi denotes the legal capacity to institute proceedings in a court of law. It is also referred to as status, standing, title or authority to sue.Per Fatayi-Williams CJN in Senator Abraham Ade Adesanya v President, Federal Republic of Nigeria, [2000] Federation Weekly Law Reports(Pt 46) 859, 884 and Per Ogundare JSC in Josiah Kayode Owodunmi vRegistered Trustees of Celestial Church of Christ \& 3 Ors [2000] 10 NWLR (Pt 675) 315, 338.

102 Example of such cases are Ken Wiwa and others v Royal Dutch Petroleum Company and A. F. Akpan v Shell \& Anor.

103 The National Conference 2014, Main Report. See [5.7.1] 147. 
future generations (intergenerational equity), which constitutes the substratum of the rights or obligations equation of sustainable development. ${ }^{104}$ On this basis, the National Assembly should create a new sub-section 2 of section 33 while the present sub-section 2 should be changed to sub-section 3 . The new sub-section 2 should read thus

The right to sustainable development is an essential requirement to the life of present and future generations of Nigerians.

Secondly, the National Assembly should strengthen the environmental and related provisions in Chapter II of the 1999 Constitution. The National Assembly can do this by (a) amending and transferring sections 20 (environmental objectives) to Chapter IV of the 1999 Constitution, and (b) amending sections 16(2)(a) (economic objectives) and 17(2)(d) (exploitation of natural resources) of the 1999 Constitution.

Section 20 of the 1999 Constitution reads: 'The state shall protect and improve the environment and safeguard the water, air and land, forest and wild life of Nigeria'. This section vests the responsibility of protection and improvement of the environment on the state and is the genesis of sections 1(2) (a) and 7(a) of the NESREA Act. The Agency is a federal government institution. Whether the word 'State' in section 20 of the 1999 Constitution is interpreted to mean 'the Federal Government' or 'all tiers of government', a controversy that the SCN Justices seriously engaged in Attorney-General of Lagos State v AttorneyGeneral of the Federation and 35 Ors,${ }^{105}$ individuals, NGOs and local communities do not have the locus standi to sue for the enforcement of sustainable development. For the purpose of ensuring the effective implementation and enforcement of sustainable development, the National Assembly should, before it transfers section 20 to Chapter IV of the 1999 Constitution, amend it by making it subsection (1) of

104 On the need to interpret the Constitution broadly see Nnamani JSC in Bronik Motors $v$ WEMA Bank (1983) ANLR, 272, 292; Peoples Democratic Party (PDP) $v$ Congress for Progressive Change (CPC) \& Ors (2011) LPELR- 2909(SC).

105 Attorney-General of Lagos State (n 91). Uwaifo and Onu JJSC construed the word 'state' in section 20 of the 1999 Constitution to mean 'a sovereign state' or 'the Federal Republic of Nigeria'. On the other hand, Kalgo, Ejiwunmi, Ayoola, Niki Tobi JJSC as well as Uwais CJN (rtd) decided that the word 'state' means all tiers of government thus reflecting the federal character ideology which underpins the meaning of the words 'government' and 'state' in section 318(1) of the 1999 Constitution. See generally Emmanuel E Okon, 'The Residue of Unitary System in the Regulation of the Environment in Nigeria (n 100) 335. 
section 20 and inserting the word 'sustainability' just after the word 'environment'. The word 'environment' should be substituted with the word 'environmental'. The new section 20(1) should read:

20 (1) 'The state shall protect and improve the environmental sustainability and safeguard the water, air and land, forest and wild life of Nigeria'.

Also, a new subsection (2) should be created and it should read:

(2) Where the state fails to perform its duties under subsection (i) of this section, individuals, non-governmental organizations or local communities may take legal action to enforce the said subsection.

The contention that the whole section 20 of the 1999 Constitution should be transferred to Chapter IV is to enable the relevant stakeholders to enforce it just like any other fundamental human rights provisions. What is more, para 3(e) of the Preamble to the 1999 Constitution Fundamental Rights (Enforcement Procedure) Rules, 2009 mandates the court to encourage and welcome public interest litigation in human rights field and no human rights case may be dismissed or struck out for want of locus standi. In particular, human rights activists, advocates or group as well as any non-governmental organization, may institute human rights application on behalf of any potential applicant. The constitutional guarantee of the right of sustainable development, environmental sustainability, and public interest litigation will definitely enhance the implementation and enforcement of sustainable development in Nigerian environmental law

Section 17(2)(d) of the 1999 Constitution provides as follows:

(2) In furtherance of the social order-

(d) exploitation of human or natural resources in any form whatsoever for reasons, other than the good of the community, shall be prevented.

This section enjoins the state to adopt policies and measures that will prevent the over-exploitation of natural resources. Within the context of sustainable development, the phrase 'the good of the community' means taking care of the economic and development expectations of communities and the long-term sustainability of their natural resources. The National Assembly should amend para (d) and 
delete the word 'good' and replace it with 'sustainability'. Paragraph (d) should read:

Exploitation of human or natural resources in any form whatsoever for reasons, other than the sustainability of the community, shall be prevented.

Presently, section 16(2) of the 1999 Constitution provides that 'The State shall direct its policy towards ensuring-

(a) 'the promotion of a planned and balanced economic development'.

Although this provision requires the state to take into consideration the contemporary approach of solving environmental problems, technically termed as sustainable development, it fails to specifically direct the state to do so. The word 'sustainable' should be inserted into para (a) after the word 'and'. In order to further strengthen this section, the word 'promote' should be substituted with the word 'attainment'. Paragraph (a) should now read:

The attainment of a planned, balanced and sustainable economic development.

Amendment of sections 17(2)(d) and 16(2)(a) as suggested will ensure congruence in all provisions of the 1999 Constitution on sustainable development.

\section{CONCLUSION}

Lowe, Bratspies, Stone did not take into account the fact that in some jurisdictions sustainable development has already acquired the status of a legal rule, expressed in their Constitutions and statutes. In Nigeria, from the NPE's perspective, sustainable development is a mere plan of action akin to soft law. As far as the NESREA Act is concerned, sustainable development is a rule of law although expressed in general terms. Its legal status as a rule of law is certain in the Desertification and Drought Regulations, and the Wetland, River Banks and Lake Shores Regulations where it is expressed as determinable, measurable and achievable objectives and principle respectively. Sustainable development is expressed with the same characteristics in the SCN's decision in Attorney-General of Lagos State v Attorney-General of the 
Federation \& 35 Ors, ${ }^{106}$ but as a procedural case law rule.

The major factors hindering the implementation and enforcement of sustainable development in Nigerian environmental law are its ordinary rule of law nature, albeit depending on which instrument is incorporated, and failure on the part of the Agency to ensure its enforcement. It is imperative that the National Assembly should, among other things, express it in precise and direct terms as an essential element to the right of life as well as integrate it into the relevant constitutional environmental provisions. More importantly, section 20 of the 1999 Constitution should be amended as suggested and transferred to Chapter IV of the Constitution. These measures will allow individuals, NGOs, and local communities to enforce it whenever the state fails to do so.

However, to avoid opening the floodgates to frivolous and bias environmental litigations, the Chief Registrar of the Court should amend the various State High Courts and Federal High Courts Civil Procedure Rules to allow for pre-trial evaluation of sustainable development cases. The aim of the evaluation is to determine whether there is a real and serious sustainable development issue for trial by a Judge. Intending private litigants should be made to deposit a minimal sum in the Courts' Registry. The deposit should be forfeited if the Chief Registrar reaches a conclusion that there is no real and serious sustainable development issue for trial.

106 Attorney General of Lagos State (n 91). 